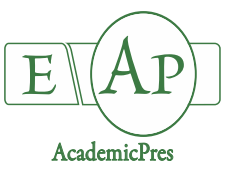

Uresti-Porras JG et al. (2021)

Notulae Botanicae Horti Agrobotanici Cluj-Napoca

Volume 49, Issue 2, Article number 12327

DOI: $10.15835 /$ nbha 49212327

Research Article

\title{
Foliar application of zinc oxide nanoparticles and grafting improves the bell pepper (Capsicum annuum L.) productivity grown in NFT system
}

\section{José G. URESTI-PORRAS ${ }^{1 *}$, Marcelino CABRERA-DE-LA FUENTE2, Adalberto BENAVIDES-MENDOZA ${ }^{2}$, Alberto SANDOVAL- RANGEL $^{2}$, Alejandro ZERMEÑO-GONZALEZ ${ }^{3}$, Raúl I. CABRERA ${ }^{4}$, Hortensia ORTEGA-ORTÍZ ${ }^{5}$}

\author{
${ }^{1}$ Antonio Narro Autonomous Agrarian University, PhD of Science in Protected Agriculture, Antonio Narro 1923, 25315, Saltillo, \\ Coahuila,México;gera_up@hotmail.com (*correspondingauthor) \\ ${ }^{2}$ Antonio Narro Autonomous Agrarian University, Department of Horticulture, Antonio Narro 1923, 25315, Saltillo, Coahuila, \\ México; abenamen@gmail.com; asandovalr@gmail.com; cafum7@yahoo.com \\ ${ }^{3}$ Antonio Narro Autonomous Agrarian University, Department of Irrigation and Drainage, Antonio Narro 1923, 25315, \\ Saltillo, Coahuila, México; azermenog@hotmail.com \\ ${ }^{4}$ Rutgers University, Department of Plant Biology, Rutgers Agricultural Research and Extension Center (RAREC), \\ Bridgeton, NJ08302,USA; cabrera@njaes.rutgers.edu \\ ${ }^{5}$ Center for Investigation of Applied Chemistry, Enrique Reyna H. No. 140, San José de los Cerritos, 25294, Saltillo, Coahuila, \\ México; hortensia.ortega@ciqa.edu.mx
}

\begin{abstract}
The bell pepper (Capsicum annuum L.) is a food vegetable with a high nutritional intake, with rich content in vitamins, minerals and antioxidants. In this study, using nutrient film technique (NFT) system, the effect of the zinc oxide nanoparticles on the micromorphology, histology, physiology and production of the grafted pepper was evaluated. The treatments used were grafted and non-grafted plants, four concentrations $\left(0,10,20,30 \mathrm{mg} \mathrm{L}^{-1}\right)$ of zinc oxide nanoparticles, and the experience was organized in a completely randomized design. An increase in grafted plants was observed in the weight, number and size of fruits in $18.1 \%, 21.8 \%$ and $9.6 \%$, the concentration $30 \mathrm{mg} \mathrm{L}^{-1}$ of nanoparticles statistically affected the weight, number and size $46.9 \%$, $47.7 \%$ and $18 \%$ compared to the control. The interaction with grafted plants and the treatment of $30 \mathrm{mg} \mathrm{L}^{-1}$ of zinc oxide nanoparticles increased fruit weight, number of fruits and size by $62.60 \%, 57.69 \%$ and $29.17 \%$ compared to plants without grafting and the control treatment. These results indicate that the use of grafts and zinc oxide nanoparticles could be used in bell pepper production to increase yield.

Keywords: histology; hydroponic; micromorphology; physiology; productivity

\section{Introduction}

The bell pepper is one of the vegetables with the highest production worldwide (FAOSTAT, 2019), the world production of bell pepper in 2019 was 1,990,926 harvested hectares, of which from which a production of 38,027,164 tons was obtained, with an average yield of $19.10 \mathrm{tha}^{-1}$ (FAO, 2019). In Mexico 152,772.55


hectares were planted, of which a production of 3,238,244.81 tons was obtained, with a yield of $21.65 \mathrm{tha} \mathrm{a}^{-1}$ (SIAP, 2019). However, the pepper also has a great contribution to human health, providing for its great nutritional value, it contains a wide range of nutritional and bio functional properties related to its phenolic compounds, flavonoids, capsaicinoids, carotenoids, tocopherols, vitamin C, A, E, B, potassium, magnesium, iron, calcium and phosphorus (Ganguly et al., 2017; Vera-Guzmán et al., 2017). It is of great importance to know the micromorphological, histological, physiological and productive processes in the bell pepper crop, since it is one of the most consumed chili peppers both fresh, dry, and processed.

The micromorphology, histology, physiology and productivity are positively modified by the graft and the use of nanoparticles in the bell pepper culture, for which varieties of commercial interest and good adaptability to conditions of the region were used. Currently there are no works in which the effects of grafting and nanoparticles and their interaction in the production of bell pepper established and grown in the nutrient film technique (NFT) system have been recorded.

Grafting is a special type of plant propagation, in which one part of a plant (scion) joined to another plant (rootstock) so that the two parts grow together and form a new plant (Rouphael et al., 2018). By selecting the appropriate rootstock and with this technology, the morphology of the scion can be manipulated, and biotic and abiotic stress can be managed (Kumar et al., 2015; Kumar et al., 2017). Nutrient uptake and utilization in horticultural crops is enhanced by selecting appropriate rootstocks, which play a vital role in manipulating the nutrient status of the shoots by directly affecting ion absorption and transport (Amiri et al., 2014). The use of suitable rootstocks tends to simultaneously improve the environmental, economic and social aspects of agriculture (Martínez-Andújar et al., 2020).

NFT is a system that uses water that contains the dissolved nutrients necessary for plant growth and can be an open or closed system in which the nutrient solution recirculates constantly being in direct contact with the root system of the plants (Cooper, 1979). This growing hydroponic technique is gaining acceptance as it provides a high return on investment, supporting the growth of the hydroponics market (Love et al., 2015). The NFT has its origins in England during the sixties, it was developed to increase the productivity of the hydroponic production sector, generally it is composed of PVC pipes, collecting tanks, recirculating pumps for the nutrient solution (Triunfo et al., 2018). It allows the reuse of nutrients, for a better use of the resource, favoring absorption in the root systems, it is considered a closed system since the nutrient solution recirculates as a sheet through the roots (Brenes and Jimenez, 2016), seek to reduce the use of water, and therefore reduce production costs, the use of grafts will benefit with greater vigor, improved plant development, and defense against abiotic stress (Huang et al., 2015; Love et al., 2015; Miglietta et al., 2017).

With nanotechnology, the effectiveness of the use of micronutrients, macronutrients, and pesticides in crops can be increased (Mazzaglia et al., 2017). A nanoparticle is defined as any designed particle with a dimension of 1 to 100 nano meters and has properties that are not shared by nanoscale particles with the same chemical composition (Auffan et al., 2009; Hajra and Mondal, 2017). However, little is known about the effect that zinc oxide nanoparticles ( $\mathrm{ZnO} \mathrm{NPs}$ ) have on the micromorphology, histology, physiology, and productivity of the grafted bell pepper. The use of grafts gives vigor, improves the absorption and transport of water and nutrients, influencing the micromorphology, histology and physiology of plants (CamposecoMontejo et al., 2018; García-López et al., 2019; Salehi et al., 2010). The application of zinc oxide nanoparticles generates oxidative stress in the plant as defense mechanisms the plant produces secondary metabolites which have an effect on the micromorphology, histology and physiology (Mantoan et al., 2016; Rossi et al., 2019; Zhu et al., 2020). The hypothesis used in this work was that micromorphology, histology, physiology, and production are positively modified by grafting and the use of $\mathrm{ZnO}$ NPs in bell pepper cultivation. Therefore, in this work we report the effects produced in 'SVEN RZ F1' bell peppers grafted and cultivated in the NFT system with foliar application of zinc oxide nanoparticles. 


\section{Materials and Methods}

The present work was carried out in the spring-summer 2020 cycle in a greenhouse located in the Department of Horticulture at the Antonio Narro Autonomous Agrarian University, Buenavista, Saltillo, Coahuila, Mexico, at latitude $25^{\circ} 21^{\prime} 23.4^{\prime \prime}$, longitude $101^{\circ} 02^{\prime} 10.6^{\prime \prime}$ and 1,760 meters above sea level Figure 1.

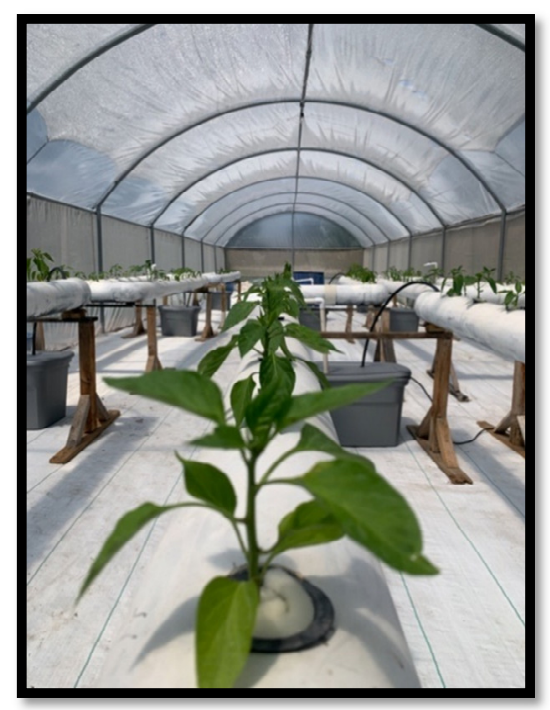

Figure 1. Established experiment; Cultivation established in greenhouse

\section{Plant material and growing conditions}

The 'SVEN RZ F1' hybrid from the Rijk Zwaan seed company is a blocky type bell pepper characterized by having short internodes, which adapts very well in greenhouses, with very good bearing and great fruit setting capacity in hot conditions. since it is a very precocious material. With fine, bright yellow fruits of very good quality, a plant with good vigor and a good generative tendency. For the rootstock, an 'ULTRON F1' pepper from the HM CLAUSE commercial seed company was chosen, which is a hybrid of indeterminate growth that has great vigor and tolerance to salinity, with a yellow blocky-type fruits.

Inside the greenhouse, an average irradiance of $4.5 \mathrm{kWh} \mathrm{m}^{-2} \mathrm{day}^{-1}$ was reached, the average recorded temperatures were a maximum of $36^{\circ} \mathrm{C}$ and a minimum of $22^{\circ} \mathrm{C}$ and the average relative humidity inside the structure was $40 \%$.

The scion was sown in a greenhouse on February 7, 2020 using a 200-cavity polystyrene tray Figure 2A, peat was used as substrate, 10 days later, on February 17, 2020, the rootstock was sown in a tray of 200 cavities, using peat as substrate and one seed per cavity. The rootstock has greater vigor and vegetative growth, which is why it was sown later, for this reason it reached the scion in size and stem width. Obtaining similarity in the thickness of the stem, which benefits the union of both plant structures.

\section{Graft}

On March 7, 2020, the grafting was performed using the splicing technique (Lee Jung Myung, 1994) when the plants had 30 days after germination Figure 2B. The splice graft was performed when both structures had a stem diameter of two millimeters. The rootstock and scion were cut at an angle of $60^{\circ}$ downwards and upwards respectively, both plant structures were joined with a $2.0 \mathrm{~mm}$ size silicone clip.

The recovery of the plants began immediately after grafting, they were kept in a holding chamber with relative humidity between 80 to $85 \%$ and a temperature of 25 to $28^{\circ} \mathrm{C}$, for 10 days. On March 17, 2020 the silicone clip was completely removed as the union between scion and rootstock had occurred and healed. The 
plants were supplied daily with water, $25 \%$ nutrient solution (Steiner, 1961), and commercial foliar amino acids Metamin Max (Agroestimulantes Mexicanos SA de CV., Aguascalientes, México) with a composition of $64.92 \%$ glutamic acid, $5.08 \%$ thiamine and $30 \%$ inert conditioners, a dose of $1 \mathrm{~g} \mathrm{~L}^{-1}$ in foliar application with a manual water spray.

\section{Nutrient Film Technique (NFT)}

The NFT system used was composed of 8 PVC pipes of 6 inches in diameter, with 16 holes of 6 centimeters wide, and with $30 \mathrm{~cm}$ between holes, 68 -liter plastic boxes were used to collect the nutrient solution, and 25-watt submersible electric pumps for fish tanks with a circulation capacity of 1500 liters per hour were used for recirculation of the nutrient solution.

\section{Transplant to NFT system}

The transplant was carried out on April 13th and 14th, 2020 Figure 2C, the substrate was removed from the seedlings rinsing with water and leaving the root free of substrate, then the root was immersed in a solution of water with $3 \%$ hydrogen peroxide as a preventive treatment against disease-causing microorganisms. Plastic baskets for hydroponics of 3 inches were used, for the adjustment of the plant inside the basket, a polyurethane sponge was used leaving the root free to have contact with the nutrient solution.

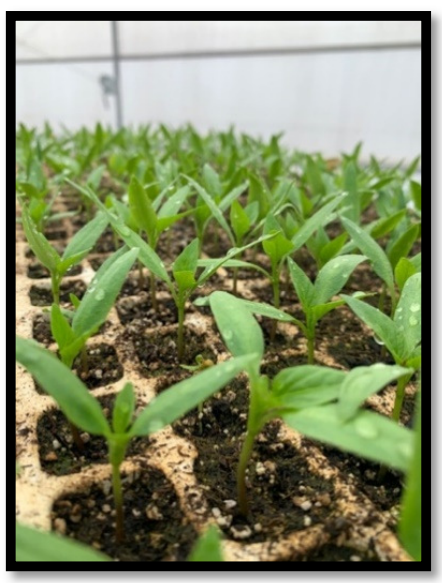

(A)

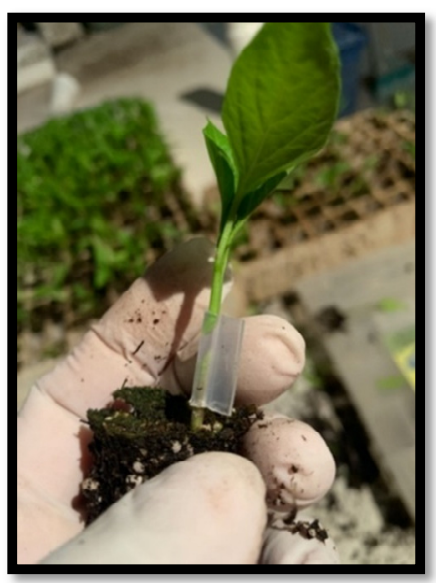

(B)

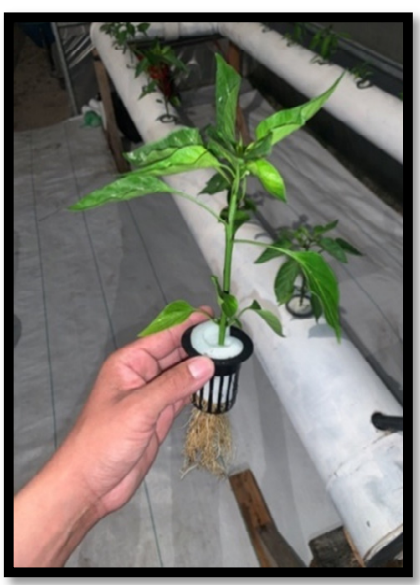

(C)

Figure 2. Establishment and work in greenhouse; (A) rootstock and scion sowing; (B) splice graft; (C) establishment in NFT system

\section{Zinc oxide nanoparticles}

The $\mathrm{ZnO}$ NPs used in the experiment were synthesized and characterized in the pilot plant of the Center for Research in Applied Chemistry (CIQA) Saltillo, Coahuila, Mexico Figure 3, their size of $52 \mathrm{~nm}$, spherical morphology, white-yellow powder appearance clear, purity $99.8 \%$ were determined by X-ray, and covered with palmitic acid.

\section{Application of the $Z n O N P s$}

The application was by foliar route 10 days after the healing of the graft, on March 27th, 2020, the different doses of nanoparticles were prepared using concentrations of $0,10,20$, and $30 \mathrm{mg} \mathrm{L}^{-1}$. The method for preparing the different doses was using a $\mathrm{ZnO}$ NPs stock solution. Subsequently, the four doses of nanoparticles were prepared, using a 1-liter volumetric flask, each of the nanoparticle concentrations were poured separately and made up with distilled water. The solutions were placed in manual sprinklers with a 
capacity of 1 liter, and the different nanoparticle treatments were applied homogeneously on the bundle, underside of the leaves and stems (shoots).

The first application of nanoparticles was in the growth stage, when the seedlings had 10 days after grafting. The second application of nanoparticles was made in the flowering stage 80 days after transplantation, the third application was made in the fruit filling stage at 95 days after transplantation, in plants already established in the NFT system. The applications were made in the afternoon when temperatures of $22{ }^{\circ} \mathrm{C}$ prevailed, to avoid any problem related to high temperatures and radiation.

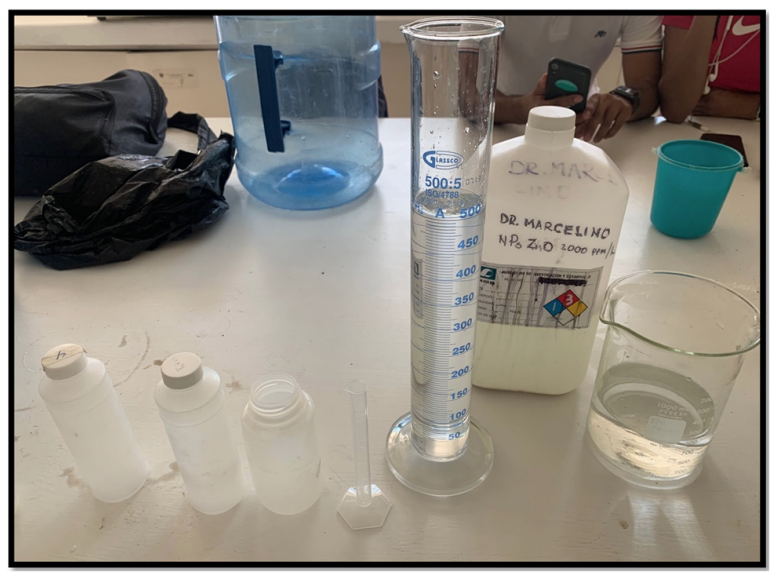

Figure 3. Photograph of zinc oxide nanoparticles; preparation of zinc oxide nanoparticles

\section{Measurement of variables (Micromorphological variables)}

Collection of epidermal samples: to determine the number, size of stomata, and tabloid cells, fully expanded young leaves were used Figure 4A. The leaves were cut at the same plant height, with the characteristics that were mature, fully expanded and with the same orientation. The impressions were taken immediately after cutting the leaves, from both sides (top and bottom) ensuring that all were from the middle part of each leaf following the methodology described in the manual (Hernández, 1984).

The material used to print the samples was PVC glue and transparent adhesive tape, paint brush, and glass microscope slides. A light layer of glue was placed on the middle part of the leaf (upper and lower side), it was left to dry for 30 seconds, then a centimeter of adhesive tape was cut and placed on the glue, allowed to dry and the adhesive tape was peeled off with the glue already attached. It was mounted on the slides, three random samples were taken per treatment (Hernández, 1984).

For the evaluation, a compound microscope (Carl Zeiss) with an integrated camera (Pixera Winder Pro) was used to capture photographs of the samples in the top and bottom for the number, width, length of stomata and number of cells epidermal figure 4B. Measurement software was used (AxionVision Rel. 4.8; Carl Zeiss) (Hernández, 1984).

\section{Stomatal density (SD)}

Stomatal density was evaluated as follows:

$\mathrm{SD}=$ number of stomata $/ 0.0247604 \mathrm{~mm}^{2}$ (photographed image area), the result obtained are stomata per $\mathrm{mm}^{2}$.

$\mathrm{SD}=$ Stomatal number/image area

\section{Stomatal index (SI)}

The stomatal index was calculated by the formula suggested by (Wilkinson, 1979). A compound microscope (Carl Zeiss) with digital camera (PixeraWinder Pro) and measurement software were used (AxionVision Rel. 4.8; Carl Zeiss). 
Represents the quotient between the number of stomata and the number of epidermal cells.

SI $=$ stomatal density/epidermal cells + number of stomata $* 100$

\section{Histological variables: number of xylem vessels and xylem vessel area}

The procedure for the histological test was as follows Figure 4C and 4D: Fixation in formaldehyde alcohol acetic acid (FAA), and dehydration with 50\% and 60\% alcohol for 30 minutes respectively, $70 \%, 80 \%$ and $96 \%$ for 3 hours, continuing with t-Butyl alcohol I, t-Butyl alcohol II, t-Butyl alcohol plus xylol in proportions of 3:1, t-Butyl alcohol plus xylol in proportions of 1:1, t-Butyl alcohol plus xylol in proportions of $1: 3$ and pure xylol, for 2 hours in each solution. The inclusion was in paraffin in an oven from $30^{\circ} \mathrm{C}$ to $55^{\circ} \mathrm{C}$. The cuts were made in a manual microtome at $18 \mu \mathrm{m}$ of thickness, and glued on slides with adhesive and heat, the staining was safranin-fast green. Finally, the tissues were sealed with a drop of Canada balsam and a slide the size of the tissue, and left to dry in an oven at $30^{\circ} \mathrm{C}$ for a week (Hernández, 1984).

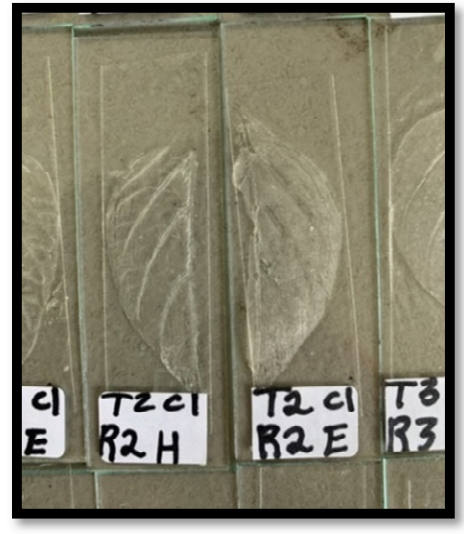

(A)

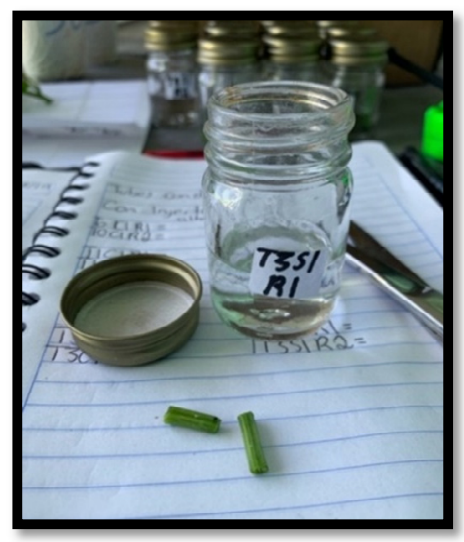

(C)

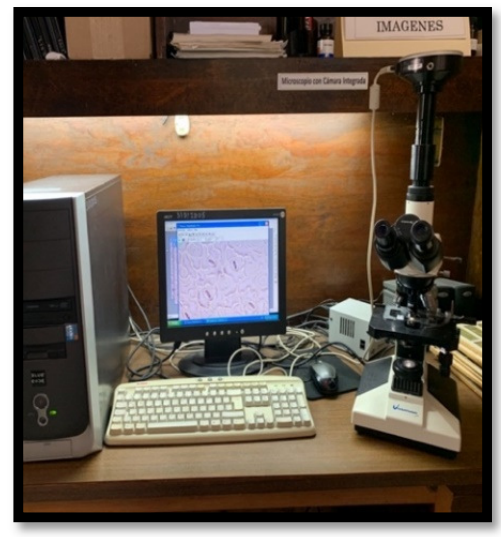

(B)

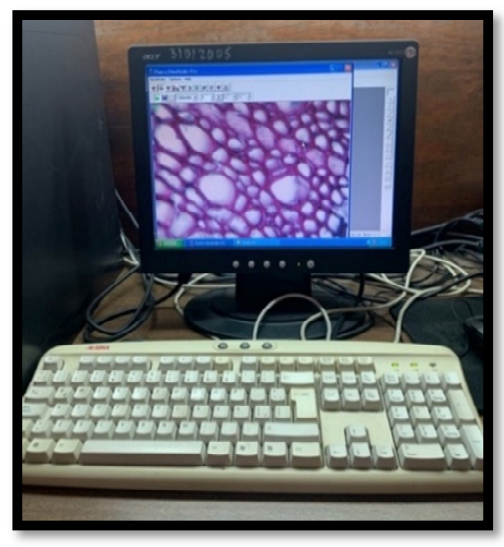

(D)

Figure 4. Sampling; (A) leaf impression on slide; (B) AxionVision Rel. 4.8 Carl Zeiss for measuring conductive tubes; (C) horizontal stem cut; (D) AxionVision Rel. 4.8 Carl Zeiss for stomata measurement

\section{Physiological variables}

For the measurement of gas exchange, a portable photosynthesis system Li-6,800 (LI-COR, Inc., Lincoln, NE, USA) was used in the phenological stage of production for being a significant stage in gas exchange, on July 22, 2020, data were taken 100 days after transplantation, taking five means per treatment, the light conditions were: light $379.20 \mu \mathrm{mol} \mathrm{m}^{-2} \mathrm{~s}^{-1} ; \mathrm{CO}_{2} 550 \mathrm{ppm}$; temperature $32^{\circ} \mathrm{C}$; relative humidity $65 \%$, data collection was during the day at 12:00 pm and with environmental conditions of a totally clear sky, a single 
measurement was made, with the PAR and $\mathrm{CO} 2$ variables fixed and there was no variation during the measurement. Figure 5A.

Production variables: fruit weight, number of fruits, polar and equatorial diameter

For the fruit weight variable, an I-2,000 Superior mini digital portable scale (METER8, Co., Shenzhen, China) was used where 5 fruits were weighed per treatment Figure 5B. The number of fruits was counted at the time of cutting Figure 5C. For the variables of polar and equatorial diameter, a HER-411 digital vernier (Electrónica Steren S.A. de C.V., Azcapotzalco, México) was used, measuring 5 fruits per treatment Figure 5D.

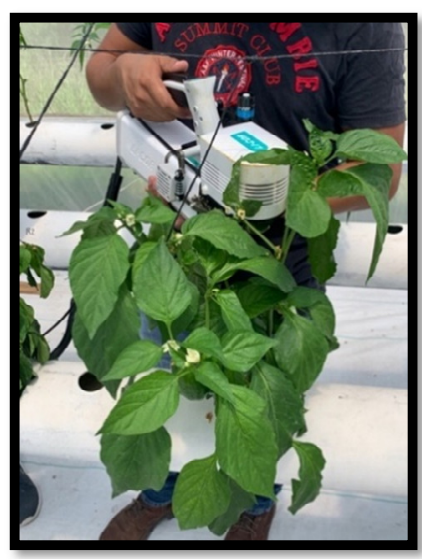

(A)

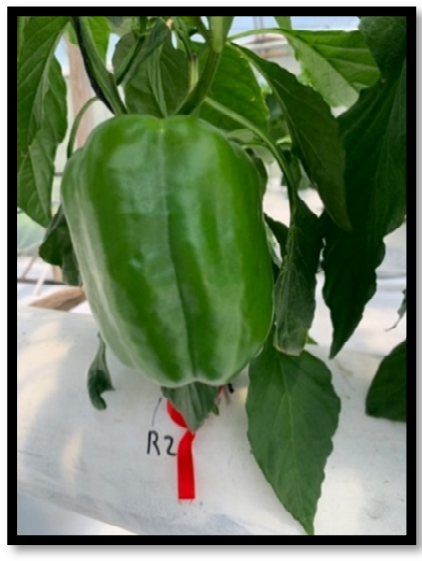

(C)

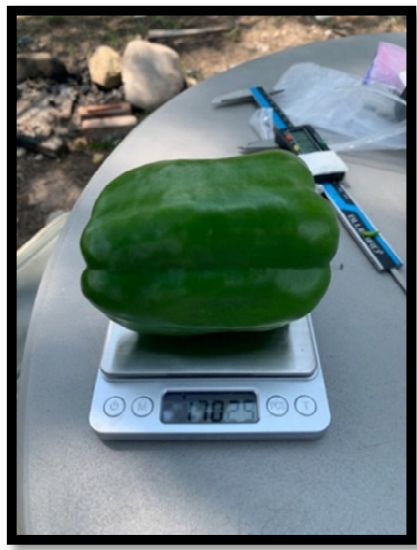

(B)

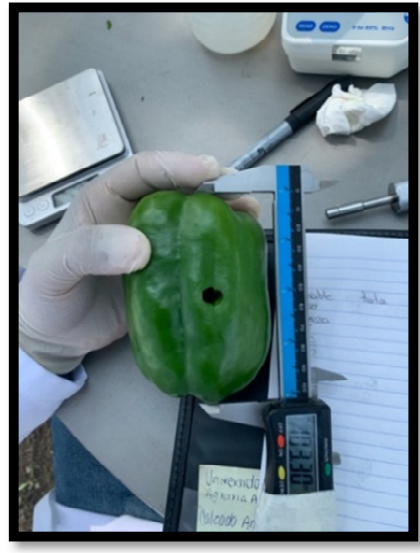

(D)

Figure 5. Production and harvest; (A) portable photosynthesis system LI-COR LI-6800; (B) fruits weight; (C) number of fruits; (D) fruits size

\section{Statistical analysis}

The experimental design used for the development of the experiment was completely random with a factorial arrangement $\left(2^{*} 4\right)$. With the data obtained, an analysis of variance (ANOVA) was carried out; for the detection of statistical differences between treatments, the test of comparison of means by Tukey was used ( $\mathrm{p}$ $\leq 0.05$ ). The factors were: with and without graft, four concentrations $0,10,20$ and $30 \mathrm{mg} \mathrm{L}^{-1}$ of zinc oxide nanoparticles resulting in eight treatments and four repetitions, statistical software was used for the analysis of the information (InfoStat version 2014 Grupo InfoStat, FCA, Universidad Nacional de Córdoba, Argentina). 


\section{Results}

\section{Micromorphological and histological results}

Results of the graft effect on the micromorphological and histological variables.

The graft affected the histological variables with statistical difference in the grafted plants in the xylem vessel area (XVA) variable, which was $37.8 \%$ greater than in plants without graft, regarding the number of xylem vessels (NXV) variable the plants without graft had a greater number of vessels by $20.1 \%$ compared to grafted plants Table 1 .

Results of the $Z n O N P$ s effect on the micromorphological and histological variables.

The application of nanoparticles statistically affected the variable of stomatal index (IE), in the concentration $30 \mathrm{mg} \mathrm{L}^{-1}$ had $3.8 \%$ higher index compared to the control, while the length of stomata on the bottom (LSB) had an increase of $12.1 \%$ compared to the concentration of $10 \mathrm{mg} \mathrm{L}^{-1}$ and $15.1 \%$ than the control. The variables length of stomata in top (LST), width of stomata in top (WST) and width of stomata bottom (WSB) did not have differences between treatments Table 1.

Table 1. Comparison of means of graft effects, $\mathrm{ZnO}$ NPs, and interaction in micromorphological and histological variables

\begin{tabular}{|c|c|c|c|c|c|c|c|c|c|}
\hline \multicolumn{2}{|c|}{ Factor } & $\mathrm{SD}\left(\mathrm{mm}^{2}\right)$ & SI (\%) & $\operatorname{SLT}(\mathrm{mm})$ & $\mathrm{LSB}(\mathrm{mm})$ & $\begin{array}{l}\text { SWT } \\
(\mathrm{mm})\end{array}$ & $\begin{array}{l}\text { WSB } \\
(\mathrm{mm})\end{array}$ & $\begin{array}{c}\text { AVX } \\
\left(\mathrm{mm}^{2}\right) \\
\end{array}$ & NVX \\
\hline \multicolumn{2}{|l|}{ Grafted } & $287.41 \mathrm{a}$ & $89.23 \mathrm{a}$ & $24.69 a$ & $23.98 \mathrm{a}$ & $14.83 \mathrm{a}$ & $17.60 \mathrm{a}$ & $233.42 b$ & $90.11 \mathrm{~b}$ \\
\hline \multicolumn{2}{|l|}{ Ungrafted } & $272.28 \mathrm{a}$ & $88.57 \mathrm{a}$ & $24.75 \mathrm{a}$ & $24.53 \mathrm{a}$ & $13.94 \mathrm{a}$ & $17.59 \mathrm{a}$ & $375.38 \mathrm{a}$ & $112.83 \mathrm{a}$ \\
\hline \multicolumn{2}{|l|}{ Control } & $216.82 \mathrm{a}$ & $87.11 \mathrm{~b}$ & $24.29 \mathrm{a}$ & $22.64 \mathrm{a}$ & $14.52 \mathrm{a}$ & $17.03 \mathrm{a}$ & $312.42 \mathrm{a}$ & $92.61 \mathrm{a}$ \\
\hline \multicolumn{2}{|l|}{$10 \mathrm{mg} \mathrm{L}^{-1}$} & $257.15 \mathrm{a}$ & $88.43 \mathrm{ab}$ & $23.30 \mathrm{a}$ & $23.44 b$ & $14.68 \mathrm{a}$ & $17.75 \mathrm{a}$ & $311.86 \mathrm{a}$ & $107.39 \mathrm{a}$ \\
\hline \multicolumn{2}{|l|}{$20 \mathrm{mg} \mathrm{L}^{-1}$} & $312.62 \mathrm{a}$ & $89.50 \mathrm{ab}$ & $25.34 \mathrm{a}$ & $24.26 \mathrm{ab}$ & $14.59 \mathrm{a}$ & $16.95 \mathrm{a}$ & $300.40 \mathrm{a}$ & $102.94 \mathrm{a}$ \\
\hline \multicolumn{2}{|l|}{$30 \mathrm{mg} \mathrm{L}^{-1}$} & $332.79 \mathrm{a}$ & $90.57 \mathrm{a}$ & $25.95 \mathrm{a}$ & $26.67 \mathrm{a}$ & $13.75 \mathrm{a}$ & $18.66 \mathrm{a}$ & $292.93 \mathrm{a}$ & $102.94 \mathrm{a}$ \\
\hline \multirow{4}{*}{ Grafted } & Control & $201.69 \mathrm{~b}$ & $86.91 \mathrm{~b}$ & $23.87 \mathrm{a}$ & $21.81 \mathrm{~b}$ & $14.94 \mathrm{a}$ & $17.43 \mathrm{a}$ & $242.52 c$ & $105.67 \mathrm{ab}$ \\
\hline & $10 \mathrm{mg} \mathrm{L}^{-1}$ & $252.11 \mathrm{~b}$ & $88.69 \mathrm{ab}$ & $23.45 \mathrm{a}$ & $23.70 \mathrm{ab}$ & $14.94 \mathrm{a}$ & $17.77 \mathrm{a}$ & $271.93 \mathrm{bc}$ & $118.44 \mathrm{a}$ \\
\hline & $20 \mathrm{mg} \mathrm{L}^{-1}$ & $262.20 \mathrm{~b}$ & $88.49 \mathrm{ab}$ & $25.75 \mathrm{a}$ & $23.89 \mathrm{ab}$ & $16.09 \mathrm{a}$ & $16.93 \mathrm{a}$ & $222.25 c$ & $115.11 \mathrm{ab}$ \\
\hline & $30 \mathrm{mg} \mathrm{L}^{-1}$ & $433.63 \mathrm{a}$ & $92.84 \mathrm{a}$ & $25.69 \mathrm{a}$ & $26.51 \mathrm{a}$ & $13.80 \mathrm{a}$ & $18.26 \mathrm{a}$ & $197.00 \mathrm{c}$ & $112.11 \mathrm{ab}$ \\
\hline \multirow{4}{*}{ Ungrafted } & Control & $262.20 \mathrm{~b}$ & $87.32 \mathrm{~b}$ & $24.71 \mathrm{a}$ & $23.47 \mathrm{a}$ & $14.10 \mathrm{a}$ & $16.62 \mathrm{a}$ & $382.32 \mathrm{a}$ & $79.56 \mathrm{~b}$ \\
\hline & $10 \mathrm{mg} \mathrm{L}^{-1}$ & $262.20 \mathrm{~b}$ & $88.18 \mathrm{ab}$ & $23.14 \mathrm{a}$ & $23.17 \mathrm{a}$ & $14.88 \mathrm{a}$ & $17.72 \mathrm{a}$ & $351.78 \mathrm{ab}$ & $96.33 \mathrm{ab}$ \\
\hline & $20 \mathrm{mg} \mathrm{L}^{-1}$ & $363.04 \mathrm{ab}$ & $90.50 \mathrm{ab}$ & $24.94 \mathrm{a}$ & $24.64 \mathrm{a}$ & $13.10 \mathrm{a}$ & $16.97 \mathrm{a}$ & $378.55 \mathrm{ab}$ & $90.78 \mathrm{ab}$ \\
\hline & $30 \mathrm{mg} \mathrm{L}^{-1}$ & $231.94 \mathrm{~b}$ & $88.30 \mathrm{ab}$ & $26.20 \mathrm{a}$ & $26.83 \mathrm{a}$ & $13.69 \mathrm{a}$ & $19.06 \mathrm{a}$ & $388.86 \mathrm{a}$ & $93.78 \mathrm{ab}$ \\
\hline \multicolumn{2}{|l|}{ Grafted } & 0.6423 & 0.4238 & 0.9363 & 0.4289 & 0.1752 & 0.9918 & $* *$ & 0.0003 \\
\hline \multicolumn{2}{|l|}{$\mathrm{ZnO} N \mathrm{NP}$} & 0.0662 & 0.0365 & 0.0569 & 0.0022 & 0.7119 & 0.2069 & 0.7722 & 0.2309 \\
\hline \multicolumn{2}{|l|}{ Graft vs NPs } & 0.0019 & 0.0521 & 0.8262 & 0.7235 & 0.2742 & 0.8393 & 0.1164 & 0.9508 \\
\hline \multicolumn{2}{|l|}{$\mathrm{CV} \%$} & 25.48 & 2.58 & 7.88 & 7.95 & 12.75 & 9.59 & 12.41 & 12.00 \\
\hline
\end{tabular}

Note: stomatal density (SD), stomatal index (SI), stomatal length on top (SLT), length of stomata in bottom (LSB), stomatal width on top (SWT), width of stomata in bottom (WSB), area of xylem vessels (AXV), number of xylem vessels $(\mathrm{NXV})$, means with different letters are significantly different, the test of comparison of means by Tukey. ns= not significant $(\mathrm{p}>0.05),{ }^{*}=$ significant $(\mathrm{p} \leq 0.05),{ }^{* *}=$ highly significant $(\mathrm{p} \leq 0.0001), \mathrm{CV}=$ coefficient of variance

\section{Results of graft vs $Z n O N P$ s interaction in micromorphological and histological variables.}

Table 1, the combination between grafting effects and application of nanoparticles, where it was found that the grafting combination and the concentration of $30 \mathrm{mg} \mathrm{L}^{-1}$ had statistical difference in the variables stomatal density (SD) and stomatal index (SI). Regarding the LSB, concentrations of $30 \mathrm{mg} \mathrm{L}-1$ in combination with grafted and non-grafted plants presented the highest values. Regarding the WXV plants without graft with the interaction $30 \mathrm{mg} \mathrm{L}^{-1}$ and control, showed significant difference to grafted plants and the concentrations of nanoparticles 10,20,30 $\mathrm{mg} \mathrm{L}^{-1}$ and control. The combination of graft effects and $10 \mathrm{mg} \mathrm{L}^{-1}$ of nanoparticles had the highest NXV. 


\section{Physiological results}

Graft results on physiological variables

The effect of the graft on the variables of $\mathrm{CO}_{2}$ assimilation (CA), stomatal conductance (SC), transpiration rate (TR), photosynthetic efficiency (PE) and efficiency in light capture (ELC) did not have statistical difference, Table 2.

\section{Results of $\mathrm{ZnO} N$ Ps in physiological variables}

The nanoparticle effect had a negative statistical difference in the concentration of $30 \mathrm{mg} \mathrm{L}^{-1}$ compared to the control, the results are described below Table 2. Regarding the variable CA, the concentration $30 \mathrm{mg} \mathrm{L}$ ${ }^{1}$ increased by $60.7 \%$ compared to the control, SC increased by $29.8 \%$ compared to the control. PE increased $29.2 \%$ compared to the control and ELC increased $60.7 \%$ compared to the control. In the variable of TR, there was no statistical difference between concentrations of 30 and $20 \mathrm{mg} \mathrm{L}^{-1}$, but the $30 \mathrm{mg} \mathrm{L}^{-1}$ concentration was $39.4 \%$ higher than the concentration of $10 \mathrm{mg} \mathrm{L}^{-1}$ and $44.8 \%$ to the control Table 2.

Results of the graft vs $\mathrm{ZnO}$ NPs interaction in the physiological variables

Physiological variables were affected by the interaction, increasing the values of CA, SC, PE and ELC. In the variable TT, on the contrary, the controls showed the lowest values Table 2. The interaction between factors did not cause a difference between plants with graft and without graft, but did with the other concentrations and the control, which affected the physiological variables.

Table 2. Comparison of means of graft effects, $\mathrm{ZnO}$ NPs, and interaction in physiological variables

\begin{tabular}{|c|c|c|c|c|c|c|}
\hline \multicolumn{2}{|c|}{ Factor } & $\begin{array}{c}\mathrm{CA} \\
\left(\mu \mathrm{mol} \mathrm{m}{ }^{-2} \mathrm{~s}^{-1}\right)\end{array}$ & $\begin{array}{c}\mathrm{SC} \\
\left(\mathrm{mol} \mathrm{m}^{-2} \mathrm{~s}^{-1}\right)\end{array}$ & $\begin{array}{c}\text { TR } \\
\left(\mathrm{mol} \mathrm{m}^{-2} \mathrm{~s}^{-1}\right)\end{array}$ & $\begin{array}{c}\mathrm{PE} \\
(\mu \mathrm{mol} / \mathrm{mmol})\end{array}$ & $\begin{array}{c}\text { ELC } \\
(\mu \mathrm{mol} / \mathrm{mmol})\end{array}$ \\
\hline \multicolumn{2}{|l|}{ Grafted } & $10.90 \mathrm{a}$ & $0.38 \mathrm{a}$ & $7.58 \mathrm{a}$ & $1.40 \mathrm{a}$ & $28.74 \mathrm{a}$ \\
\hline \multicolumn{2}{|l|}{ Ungrafted } & $11.80 \mathrm{~b}$ & $0.39 \mathrm{a}$ & $8.03 \mathrm{a}$ & $1.43 \mathrm{a}$ & $31.12 \mathrm{a}$ \\
\hline \multicolumn{2}{|l|}{ Control } & $6.57 \mathrm{~d}$ & $0.33 \mathrm{c}$ & $5.51 \mathrm{~b}$ & $1.19 \mathrm{c}$ & $17.32 \mathrm{~d}$ \\
\hline \multicolumn{2}{|l|}{$10 \mathrm{mg} \mathrm{L}^{-1}$} & $8.20 \mathrm{c}$ & $0.38 \mathrm{bc}$ & $6.05 \mathrm{~b}$ & $1.36 \mathrm{~b}$ & $21.62 c$ \\
\hline \multicolumn{2}{|l|}{$20 \mathrm{mg} \mathrm{L}^{-1}$} & $13.91 \mathrm{~b}$ & $0.39 \mathrm{~b}$ & $9.68 \mathrm{a}$ & $1.44 \mathrm{~b}$ & $36.68 \mathrm{~b}$ \\
\hline \multicolumn{2}{|l|}{$30 \mathrm{mg} \mathrm{L}^{-1}$} & $16.71 \mathrm{a}$ & $0.47 \mathrm{a}$ & $9.98 \mathrm{a}$ & $1.68 \mathrm{a}$ & $44.08 \mathrm{a}$ \\
\hline \multirow{4}{*}{ Grafted } & Control & $6.59 \mathrm{~d}$ & $0.33 c$ & $5.45 \mathrm{~b}$ & $1.21 \mathrm{c}$ & $17.37 \mathrm{~d}$ \\
\hline & $10 \mathrm{mg} \mathrm{L}^{-1}$ & $7.95 \mathrm{~d}$ & $0.37 \mathrm{bc}$ & $5.95 \mathrm{~b}$ & $1.34 \mathrm{bc}$ & $20.97 \mathrm{~d}$ \\
\hline & $20 \mathrm{mgL}^{-1}$ & $12.87 \mathrm{c}$ & $0.41 \mathrm{abc}$ & $10.50 \mathrm{a}$ & $1.45 \mathrm{bc}$ & $33.92 \mathrm{c}$ \\
\hline & $30 \mathrm{mg} \mathrm{L}^{-1}$ & $16.19 \mathrm{~d}$ & $0.43 \mathrm{a}$ & $8.78 \mathrm{a}$ & $1.62 \mathrm{a}$ & $42.69 \mathrm{a}$ \\
\hline \multirow{4}{*}{ Ungrafted } & Control & $6.55 \mathrm{~d}$ & $0.33 \mathrm{c}$ & $5.57 \mathrm{~b}$ & $1.17 \mathrm{c}$ & $17.28 \mathrm{~d}$ \\
\hline & $10 \mathrm{mg} \mathrm{L}^{-1}$ & $8.45 \mathrm{~d}$ & $0.38 b c$ & $6.16 \mathrm{~b}$ & $1.38 \mathrm{bc}$ & $22.28 \mathrm{~d}$ \\
\hline & $20 \mathrm{mg} \mathrm{L}^{-1}$ & $14.96 \mathrm{~b}$ & $0.37 \mathrm{bc}$ & $10.50 \mathrm{a}$ & $1.44 \mathrm{bc}$ & $39.45 \mathrm{~b}$ \\
\hline & $30 \mathrm{mg} \mathrm{L}^{-1}$ & $17.24 \mathrm{a}$ & $0.50 \mathrm{a}$ & $9.89 \mathrm{a}$ & $1.74 \mathrm{a}$ & $45.46 \mathrm{a}$ \\
\hline \multicolumn{2}{|l|}{ Grafted } & 0.0057 & 0.4896 & 0.0909 & 0.4684 & 0.0572 \\
\hline \multicolumn{2}{|l|}{$\mathrm{ZnONPs}$} & ** & ** & ** & ** & ** \\
\hline \multicolumn{2}{|c|}{ Graft vs NPs } & 0.0985 & 0.1086 & 0.0802 & 0.5689 & 0.0983 \\
\hline \multicolumn{2}{|l|}{ CV \% } & 7.40 & 10.60 & 9.19 & 8.5 & 7.41 \\
\hline
\end{tabular}

Note: $\mathrm{CO}_{2}$ assimilation (CA), stomatal conductance (SC), transpiration rate (TR), photosynthetic efficiency (PE) and efficiency in light capture (ELC), means with different letter are significantly different, the test of comparison of means by Tukey. $n s=$ not significant $(\mathrm{p}>0.05),{ }^{*}=$ significant $(\mathrm{p} \leq 0.05),{ }^{* *}=$ highly significant $(\mathrm{p} \leq 0.0001), \mathrm{CV}=$ coefficient of variance

\section{Production results}

\section{Results of the graft on the productive variables}

The graft statistically increased the fruit weight (FW) with fruits with $21.8 \%$ increase, the number of fruits (NF) by $18.1 \%$, and the polar diameter (PD) in fruits presented a $9.6 \%$ greater diameter compared to plants without graft Table 3 . 
Results of the ZnO NPs on the productive variables

The application of nanoparticles statistically influenced the variables FW, NF, PD and equatorial dimeter (ED), with statistical difference between different concentrations. PF was affected with an increase in weight of $46.9 \%$ compared to the control. Regarding the NF the treatment $30 \mathrm{mg} \mathrm{L}^{-1}$ increased $47.7 \%$ compared to the control. The PD did not have difference between the concentrations of 30,20 and $10 \mathrm{mg} \mathrm{L}^{-1}$, but it was compared to the control, where the difference in diameter was $18 \%$. Regarding the ED, the concentrations of 30,20 , and $10 \mathrm{mg} \mathrm{L}^{-1}$ did not show a difference between them, in the same way the concentration of $10 \mathrm{mg} \mathrm{L}^{-1}$ and the control did not have statistical difference. On the other hand, the concentration of $20 \mathrm{mg} \mathrm{L}^{-1}$ presented an increase of $16.1 \%$ and the concentration of $30 \mathrm{mg} \mathrm{L}^{-1}$ a $20.2 \%$ greater in the equatorial diameter compared to the control Table 3.

Results of the interaction between graft vs $\mathrm{ZnO}$ NPs in the productive variables

The combination of effects influenced the production variables Table 3, where the highest results were obtained when using grafted plants and the application of nanoparticles at a concentration of $30 \mathrm{mg} \mathrm{L}^{-1}$ compared to the lowest results obtained by the combination of plants without grafting and the control treatment.

Table 3. Comparison of means of the graft effects, $\mathrm{ZnO}$ NPs, and interaction in the productive variables

\begin{tabular}{|c|c|c|c|c|c|}
\hline \multicolumn{2}{|c|}{ Factor } & FW (g) & $\mathrm{NF}$ & $\mathrm{PD}(\mathrm{mm})$ & $\mathrm{ED}(\mathrm{mm})$ \\
\hline \multicolumn{2}{|l|}{ Grafted } & $95.64 \mathrm{a}$ & $3.60 \mathrm{a}$ & $77.58 \mathrm{a}$ & $67.85 \mathrm{a}$ \\
\hline \multicolumn{2}{|l|}{ Ungrafted } & $74.83 \mathrm{~b}$ & $2.95 \mathrm{~b}$ & $70.14 b$ & $64.85 \mathrm{a}$ \\
\hline \multicolumn{2}{|l|}{ Control } & $61.97 \mathrm{~b}$ & $2.30 \mathrm{c}$ & $65.38 \mathrm{~b}$ & $58.37 \mathrm{~b}$ \\
\hline \multicolumn{2}{|l|}{$10 \mathrm{mg} \mathrm{L}^{-1}$} & $81.99 \mathrm{~b}$ & $3.00 \mathrm{~b}$ & $75.24 \mathrm{a}$ & $63.92 \mathrm{ab}$ \\
\hline \multicolumn{2}{|l|}{$20 \mathrm{mg} \mathrm{L}^{-1}$} & $80.26 \mathrm{~b}$ & $3.40 \mathrm{~b}$ & $75.06 \mathrm{a}$ & $69.56 \mathrm{a}$ \\
\hline \multicolumn{2}{|l|}{$30 \mathrm{mg} \mathrm{L}^{-1}$} & $116.72 \mathrm{a}$ & $4.40 \mathrm{a}$ & $79.75 \mathrm{a}$ & $73.13 \mathrm{a}$ \\
\hline \multirow{4}{*}{ Grafted } & Control & $69.26 \mathrm{bc}$ & $2.40 \mathrm{c}$ & $68.94 \mathrm{bc}$ & $63.94 \mathrm{bc}$ \\
\hline & $10 \mathrm{mg} \mathrm{L}^{-1}$ & $83.22 \mathrm{~b}$ & $3.20 \mathrm{~b}$ & $76.28 \mathrm{~b}$ & $59.32 \mathrm{~cd}$ \\
\hline & $20 \mathrm{mg} \mathrm{L}^{-1}$ & $83.87 \mathrm{~b}$ & $3.60 \mathrm{~b}$ & $77.82 \mathrm{~b}$ & 70.64 \\
\hline & $30 \mathrm{mg} \mathrm{L}^{-1}$ & $146.22 \mathrm{a}$ & $5.20 \mathrm{a}$ & $87.28 \mathrm{a}$ & $77.48 \mathrm{a}$ \\
\hline \multirow{4}{*}{ Ungrafted } & Control & $54.68 \mathrm{c}$ & $2.20 \mathrm{c}$ & $61.82 \mathrm{c}$ & $52.80 \mathrm{~d}$ \\
\hline & $10 \mathrm{mg} \mathrm{L}^{-1}$ & $80.76 \mathrm{~b}$ & $2.80 \mathrm{bc}$ & $74.20 \mathrm{~b}$ & $68.52 \mathrm{bc}$ \\
\hline & $20 \mathrm{mg} \mathrm{L}^{-1}$ & $76.64 \mathrm{~b}$ & $3.20 \mathrm{bc}$ & $72.30 \mathrm{bc}$ & $68.48 \mathrm{bc}$ \\
\hline & $30 \mathrm{mg} \mathrm{L}^{-1}$ & $87.23 \mathrm{~b}$ & $3.60 \mathrm{~b}$ & $72.22 \mathrm{bc}$ & $66.78 \mathrm{bc}$ \\
\hline \multicolumn{2}{|l|}{ Grafted } & ** & 0.0002 & 0.0003 & 0.0959 \\
\hline \multicolumn{2}{|l|}{$\mathrm{ZnO} N \mathrm{NP}$} & ** & ** & ** & $* *$ \\
\hline \multicolumn{2}{|c|}{ Graft vs NPs } & $* *$ & 0.0337 & 0.1005 & 0.0005 \\
\hline \multicolumn{2}{|l|}{$\mathrm{CV} \%$} & 12.15 & 16.14 & 7.91 & 8.27 \\
\hline
\end{tabular}

Note: fruits weight (FW), number of fruits (NF), polar diameter (PD), equatorial diameter (ED), means with different letters are significantly different, the test of comparison of means by Tukey. ns $=$ not significant $(p>0.05),{ }^{*}=$ significant $(\mathrm{p} \leq 0.05),{ }^{* *}=$ highly significant $(\mathrm{p} \leq 0.0001), \mathrm{CV}=$ coefficient of variance

\section{Discussion}

The results obtained in this study Table 1 had a smaller area of xylem vessels and a lower number of vessels, increasing the efficiency in xylem translocation, and concur with the results obtained by Salehi et al. (2010) where all grafted plants tended to carry higher amounts of xylem sap than non-grafted plants. Albornoz et al. (2020) reported that grafted plants had a higher number of xylem vessels, compared to the control (nongrafted plants). The results of this experiment concur with those found by Camposeco et al. (2018) where in bell pepper leaves, the length of the stomata were statistically significant, greater in the grafted bell pepper, 
which exceeded the ungrafted bell pepper by 8.64 and $11.22 \%$, in the same way it was also reported that the stomatal index and density were increased with the use of the rootstock, which increased the gas exchange and the photosynthetic efficiency of the plants. The results are similar to those reported by Albornoz et al. (2020) where the number of vessels and their diameter, in the graft treatment, were similar in the autografted plants and the non-grafted treatment. Vascular connectivity through the xylem was closely correlated with the appearance of continuous elements of the xylem across the graft junction (Melnyk et al., 2015). Orsini et al. (2013); Penella et al. (2017) reported that the use of tolerant rootstocks improves the photosynthesis performance of the scion under abiotic stress conditions. Xu et al. (2016); Baron et al. (2018) reported that the gas exchange of the leaves in grafted plants is directly affected by grafting, by modifying the vigor and productivity of the scion species. On the other hand, grafting does not influence the micromorphology of the plants compared to plants without grafting.

Physiology was not affected by the use of grafts Table 2, on the other hand, a trend was shown in the nanoparticle effect with the concentration of $30 \mathrm{mg} \mathrm{L}^{-1}$, the results agree with those reported by García-López et al. (2019) in habanero pepper where foliar application with $\mathrm{ZnO}$ NPs at $1000 \mathrm{mg} \mathrm{L}^{-1}$ had a greater impact on plant growth and physiology than conventional $\mathrm{Zn}$ salts $\left(\mathrm{ZnSO}_{4}\right)$, which was probably due to a greater capacity to be absorbed by the leaf. Rossi et al. (2019), Raliya et al. (2015) reported that $\mathrm{ZnO} N P s$ had a dual role of being an essential nutrient and a cofactor for nutrient mobilizing enzymes. Zhu et al. (2020) reported that the application of $\mathrm{Zn}$ increases endogenous hormones (auxins, gibberellins, and melatonin) and improves the activities of aquaporins and the antioxidant system, which in turn support photosynthetic efficiency. Regarding the interaction of factors, a trend was found in the concentrations of $30 \mathrm{mg} \mathrm{L}^{-1}$ without being affected by the graft. The reason is probably due to the greater assimilation of $\mathrm{Zn}$ when applied in the form of $\mathrm{ZnO} N P$ s due to its greater ability to penetrate the leaf (Rossi et al., 2019). Regarding the assimilation variables Mantoan et al. (2016) concluded in work with Annona emarginata which is used as a standard for Atemoya, it had a balance between perspiration and the rate of $\mathrm{CO}_{2}$ assimilation to optimize the efficiency of water use, it presents adjustments in gas exchange and the photochemical process. Our results Table 2, concur with those obtained by Dabirian and Miles (2017) who found that there was a longer graft survival due to the reduction in stomatal conductance and the probable simultaneous reduction in perspiration. The results differ from those obtained by Ayala-Arreola (2010) the interaction of graft and nanoparticles affected the increase in the rate of perspiration, the rate of assimilation of $\mathrm{CO}_{2}$, and stomatal conductance.

The use of grafts affected the productive variables Table 3, where the weight of fruits, number of fruits, and polar diameter increased, the results agree with those obtained by Velasco-Alvarado et al. (2019) where grafted plants obtained a yield of $7.4 \mathrm{~kg}$ per plant, the yield stood out with $19 \%$ compared to the plants without grafting $6.2 \mathrm{~kg}$ per plant. Fruit weight was influenced by rootstock, but it was not affected by grafting Ergun and Aktas (2018) reported that when using bell pepper grafts it produced about $12 \%$ more yield than the control plant without grafting. Soteriou and Kyriacou (2015) reported a study about watermelon that grafting increased the commercial yield by $43 \%$ on average over non-grafted controls. Riga (2015) reported grafting effects that influence most of the quality characteristics of tomato have been strongly influenced by the patternstem combination.

The use of $\mathrm{ZnO} N P s$ in the concentration of $30 \mathrm{mg} \mathrm{L}^{-1}$ had a tendency to increase since when applying them the results of higher fruit weight, number of fruits, polar and equatorial diameter were obtained, the results agree with those reported by García-López et al. (2019) in habanero pepper where similarly, the maximum average weight of the fruit was obtained with $\mathrm{ZnO} N P s$ at $1000 \mathrm{mg} \mathrm{L}^{-1}$, exceeding the control treatment by 7\%. Du et al. (2019); Servin et al. (2015) reported that the application of ZnO NPs in all treatments increased wheat grain yield, Adhikari et al. (2016) reported that when applying a coating of $50 \mathrm{mg}$ of $\mathrm{ZnO} N P s$ in corn seeds, it promoted the weight of $22.35 \mathrm{~g}$ dry sprout, compared to the control without NPs with 13.70 g. Elizabath et al. (2017) reported in a study carried out on carrots with applications of zinc oxide fertilizers, the yield and growth of the plant were increased compared to the control treatment. Saadati et al. (2016) reported results of higher fruit weight with the application of $\mathrm{Zn}$ with an average of $3.16 \mathrm{~kg}$. Zinc is a 
promoter in the production of phytohormones which promote an increase in the development and production of fruits, it obtained a significant difference compared to the control treatment $3.08 \mathrm{~kg}$ (Elizabath et al., 2017). The application of $\mathrm{Zn}$ increases endogenous hormones (auxins, gibberellins, and melatonin) which will benefit growth, development and fruit production (Zhu et al., 2020).

The interaction, grafting and $30 \mathrm{mg} \mathrm{L}^{-1}$ of nanoparticles directly influenced productivity with a trend in all variables and obtaining the highest productive values, works carried out by García-López et al. (2019) reported the maximum average fruit weight with the application of $\mathrm{ZnO} N$ ss at $1000 \mathrm{mg} \mathrm{L}^{-1}$, exceeding the control treatment by $7 \%$ and the $\mathrm{ZnSO}_{4}$ treatment by $3.6 \%$ Penella et al. (2017) reported that in grafted tomato plants increased commercial yield compared to non-grafted plants ( 44 and $40 \%$ more, respectively). Ergun and Aktas (2018) reported that the length of the fruit was significantly influenced by the graft.

\section{Conclusions}

The graft did not affect the micromorphology, but it did affect the histology where the number of vessels and the area of xylem vessels increased. Physiology was not affected by the use of grafts; on the other hand, the productive variables increased, such as the weight of fruits, number of fruits and polar diameter. The application of $\mathrm{ZnO}$ NPs affected the micromorphology by increasing the stomatal density, the stomatal index, and the length of the bottom stomata. The nanoparticles did not affect the histology, while they did affect the physiology, where the assimilation of $\mathrm{CO}_{2}$, stomatal conductance, transpiration rate, photosynthetic efficiency, efficiency in light collection, productivity showed a favorable effect, which translates into fruit weight, polar diameter and equatorial diameter. The interaction between factors affected the micromorphology by increasing the stomatal density, stomatal index, and length of stomata in the bottom, histology was affected by the interaction in the area of xylem vessels and the number of xylem vessels, physiology only had an effect in the largest applications of nanoparticles, increasing the assimilation of $\mathrm{CO}_{2}$, stomatal conductance, transpiration rate, photosynthetic efficiency, and efficiency in light capture. Productivity increased with the interaction, having the best results in weight of fruits, number of fruits, polar and equatorial diameter. Due to the results obtained in this work, we recommend the use of grafts and the foliar application of $\mathrm{ZnO} \mathrm{NP}$, which could be used in the production of bell pepper to increase productivity.

\section{Authors' Contributions}

Contributions (JU); Formal analysis; Funding acquisition; Investigation; Methodology; Project administration; Writing - original draft; Writing - review and editing, (MC, AB, AS); Project administration; Supervision; Validation; Funding acquisition, (AZ, RC, HO); Resources; Visualization; Supervision: All authors read and approved the final manuscript.

\section{Acknowledgements}

This research received no specific grant from any funding agency in the public, commercial, or not-forprofit sectors. 


\section{Conflict of Interests}

The authors declare that there are no conflicts of interest related to this article.

\section{References}

Adhikari T, Kundu S, Rao AS (2016). Zinc delivery to plants through seed coating with nano-zinc oxide particles. Journal of Plant Nutrition 39(1):136-146. https://doi.org/10.1080/01904167.2015.1087562

Albornoz F, Pérez-Donoso AG, Leigh Urbina J, Monasterio M, Gómez M, Steinfort Ú (2020). Nitrate transport rate in the xylem of tomato plants grafted onto a vigorous rootstock. Agronomy 10(2):182. https://doi.org/10.3390/agronomy10020182

Amiri ME, Fallahi E, Safi-Songhorabad M (2014). Influence of rootstock on mineral uptake and scion growth of 'Golden Delicious' and 'Royal Gala' apples. Journal of Plant Nutrition 37:16-29. https://doi.org/10.1080/01904167.2013.792838

Auffan M, Rose J, Bottero JY, Lowry GV, Jolivet JP, Wiesner MR (2019). Towards a definition of inorganic nanoparticles from an environmental, health and safety perspective. Nature Nanotechnology 4(10):634-641. https://doi.org/10.1038/nnano.2009.242

Ayala-Arrelola JC, Barrientos-Preiego AF, Colinas-León MT, Sahagún-Castellanos, Reyes-Alemán JC (2010). Relaciones injerto-interinjerto y caracteristícas anatómicas y fisiológicas de la hoja de cuatro genotipos de aguacate [Graftintergraft relationships and anatomical and physiological characteristics of the leaf of four avocado genotypes]. Revista Chapingo Serie Horticultura 16(2):147-154. https://doi.org/10.5154/r.rchsh.2010.16.018

Baron D, Amaro ACE, Macedo AC, Boaro CSF, Ferreira G (2018). Gas exchange, growth and ion concentration. Revista Brasileira de Botanica 41(1):219-225. https://doi.org/10.1007/s40415-017-0421-0

Brenes L, Jimenez MF (2016). Manual de producción hidropónica para hortalizas de hoja en sistema NFT (Nutrient Film Technique) [ Handbook of hydroponic production for leafy vegetables in NFT system (Nutrient Film Technique)]. (1st Ed). Cartago, Costa Rica. Tecnología de Costa Rica.

Camposeco-Montejo N, Robledo-Torres V, Ramírez-Godina F, Valdez-Aguilera LA, Cabrera-de-la-Fuente M, MendozaVillareal R (2018). Efecto del portainjerto en el índice y densidad estomática de pimiento morrón Capsicum annuum var. annuum [Effect of the rootstock on the stomatal index and density of bell pepper Capsicum annuum var. annuum]. Ecosistemas y Recursos Agropecuarios 5(15):555-561. https://doi.org/10.19136/era.a5n15.1539

Cooper A (1979). The ABC of NFT. Nutrient film technique. Grower Books.

Dabirian S, Miles CA (2017). Antitranspirant application increases grafting success of watermelon. HortTechnology 27(4):494-501. https://doi.org/10.21273/HORTTECH03739-17

Du W, Yang J, Peng Q, Liang X, Mao H (2019). Comparison study of zinc nanoparticles and zinc sulphate on wheat growth: From toxicity and zinc biofortification. Chemosphere 227:109-116. https://doi.org/10.1016/j.chemosphere.2019.03.168

Elizabath A, Bahadur V, Misra P, Prasad VM, Thomas T (2017). Effect of different concentrations of iron oxide and zinc oxide nanoparticles on growth and yield of carrot (Daucus carota L.). Journal of Pharmacognosy and Phytochemistry 6(4):1266-1269.

Ergun V, Aktas H (2018). Effect of grafting on yield and fruit quality of pepper (Capsicum annuum L.) grown under open field conditions. Scientific Papers Series B-Horticulture 62:463-466.

Espinoza STL, Peña AR, Valqui NCV, Chávez JCN (2019). Comportamiento productivo de 11 variedades de lechuga (Lactuca sativa L.) en sistema hidropónico NFT recirculante (Chachapoyas-Amazonas) [Productive performance of 11 lettuce varieties in a recirculating NFT hydroponic system]. Revista de Investigación de Agroproducción Sustentable 2(1):50-56. https://doi.org/10.25127/aps.20181.384

FAO (2019). Food and Agriculture Organization of de United Nations. Retrieved 2020 September 12 from http://www.fao.org/faostat/es/\#data/QC

FAOSTAT (2019). Food and Agriculture Organization of de United Nations. Retrieved 2020 September 20 from http://www.fao.org/faostat/es/\#data/PP

Ganguly S, Praveen PK, Para PA, Sharma V (2017). Medicinal Properties of chilli pepper in human diet: an editorial. ARC Journal of Public Health and Community Medicine 2(1):6-7. https://doi.org/10.20431/2456-0596.0201002 
García-López, JI, Niño-Medina G, Olivares-Sáenz E, Lira-Saldivar RH, Barriga-Castro ED, Vázquez-Alvarado R, ZavalaGarcía F (2019). Foliar application of zinc oxide nanoparticles and zinc sulfate boosts the content of bioactive compounds in habanero peppers. Plants 8(8):254. https://doi.org/10.3390/plants8080254

Hajra A, Mondal NK (2017). Effects of $\mathrm{ZnO}$ and $\mathrm{TiO}_{2}$ nanoparticles on germination, biochemical and morphoanatomical attributes of Cicer arietinum L. Energy, Ecology and Environment 2(4):277-288. https://doi.org/10.1007/s40974-017-0059-6

Hernández F (1984). Manual de Laboratorio de Citología y Citogenética [Cytology and Cytogenetics Laboratory Manual]. (1st Ed). Saltillo, Coahuila, México. Universidad Autónoma Agraria Antonio Narro.

Huang W, Liao S, Lv H, Khaldun ABM, Wang Y (2015). Characterization of the growth and fruit quality of tomato grafted on a woody medicinal plant, Lycium chinense. Scientia Horticulturae 197:447-453. https://doi.org/10.1016/j.scienta.2015.10.005

Kumar P, Lucini L, Rouphael Y, Cardarelli M, Kalunke RM, Colla G (2015). Insight into the role of grafting and arbuscular mycorrhiza on cadmium stress tolerance in tomato. Frontiers in Plant Science 6:477. https://doi.org/10.3389/fpls.2015.00477

Kumar UJ, Bahadur V, Prasad VM, Mishra S, Shukla PK (2017). Effect of different concentrations of iron oxide and zinc oxide nanoparticles on growth and yield of strawberry (Fragaria x ananassa Duch) cv. Chandler. International Journal of Current Microbiology and Applied Sciences 6(8):2440-2445. https://doi.org/10.20546/ijcmas.2017.608.288

Lee JM (1994). Cultivation of grafted vegetables I. Current status, grafting methods, and benefits. HortScience 29(4):235-239. https://doi.org/10.21273/hortsci.29.4.235

Love DC, Fry JP, Li X, Hill ES, Genello L, Semmens K, Thompson RE (2015). Commercial aquaponics production and profitability: Findings from an international survey. Aquaculture 435:67-74. https://doi.org/10.1016/j.aquaculture.2014.09.023

Mantoan LPB, de Almeida LFR, Macedo AC, Ferreira G, Boaro CSF (2016). Photosynthetic adjustment after rehydration in Annona emarginata. Acta Physiologiae Plantarum 38(6):1-11. https://doi.org/10.1007/s11738016-2171-1

Martínez-Andújar C, Albacete A, Pérez-Alfocea F (2018). Rootstocks for increasing yield stability and sustainability in vegetable crops. In: XXX International Horticultural Congress IHC2018: II International Symposium on Soilless Culture and VIII International 1273:449-470. https://doi.org/10.17660/ActaHortic.2020.1273.58

Mazzaglia A, Fortunati E, Kenny JM, Torre L, Balestra GM (2017). Nanomaterials in plant protection. In: Nanotechnology in Agriculture and Food Science 113-134. https://doi.org/10.1002/9783527697724.ch7

Melnyk CW, Schuster C, Leyser O, Meyerowitz EM (2015). A developmental framework for graft formation and vascular reconnection in Arabidopsis thaliana. Current Biology 25(10):1306-1318. https://doi.org/10.1016/j.cub.2015.03.032

Orsini F, Sanoubar R, Oztekin GB, Kappel N, Tepecik M, Quacquarelli C, Gianquinto G (2013). Improved stomatal regulation and ion partitioning boosts salt tolerance in grafted melon. Functional Plant Biology 40(6):628-636. https://doi.org/10.1071/FP12350

Paolo Miglietta P, De Leo F, Toma P (2017). Environmental Kuznets curve and the water footprint: An empirical analysis. Water and Environment Journal 31(1):20-30. https://doi.org/10.1111/wej.12211

Penella C, Nebauer SG, López-Galarza S, Quiñones A, San Bautista A, Calatayud Á (2017). Grafting pepper onto tolerant rootstocks: An environmental-friendly technique overcome water and salt stress. Scientia Horticulturae 226:3341. https://doi.org/10.1016/j.scienta.2017.08.020

Raliya R, Nair R, Chavalmane S, Wang WN, Biswas P (2015). Mechanistic evaluation of translocation and physiological impact of titanium dioxide and zinc oxide nanoparticles on the tomato (Solanum lycopersicum L.) plant. Metallomics 7(12):1584-1594. https://doi.org/10.1039/c5mt00168d

Riga P (2015). Effect of rootstock on growth, fruit production and quality of tomato plants grown under low temperature and light conditions. Horticulture, Environment, and Biotechnology 56(5):626-638. https://doi.org/10.1007/s13580-015-0042-0

Rossi L, Fedenia LN, Sharifan H, Ma X, Lombardini L (2019). Effects of foliar application of zinc sulfate and zinc nanoparticles in coffee (Coffea arabica L.) plants. Plant Physiology and Biochemistry 135:160-166. https://doi.org/10.1016/j.plaphy.2018.12.005

Rouphael Y, Kyriacou MC, Colla G (2018). Vegetable grafting: A toolbox for securing yield stability under multiple stress conditions. Frontiers in Plant Science 8:2255. https://doi.org/10.3389/fpls.2017.02255 
Saadati S, Moallemi N, Mortazavi SMH, Seyyednejad SM (2016). Foliar applications of zinc and boron on fruit set and some fruit quality of olive. Crop Research 29(2):53 https://doi.org/10.5958/2229-4473.2016.00021.5

Saadati S, Moallemi N, Mortazavi SMH, Seyyednejad SM (2016) Foliar applications of zinc and boron on fruit set and some fruit quality of olive. Vegetos 29(2):53-57. doi: 10.5958/2229-4473.2016.00021.5

Salehi R, Kashi A, Lee JM, Babalar M, Delshad M, Lee SG, Huh YC (2010). Leaf gas exchanges and mineral ion composition in xylem sap of iranian melon affected by rootstocks and training methods. HortScience 45(5):766770. https://doi.org/10.21273/HORTSCI.45.5.766

Servin A, Elmer W, Mukherjee A, De la Torre-Roche R, Hamdi H, White JC, Dimkpa C (2015). A review of the use of engineered nanomaterials to suppress plant disease and enhance crop yield. Journal of Nanoparticle Research 17(2):1-21. https://doi.org/10.1007/s11051-015-2907-7

SIAP (2019). Servicio de Información Agroalimentaria y Pesquera [Agri-Food and Fisheries Information Service]. Retrieved 2020 October 20 from https://nube.siap.gob.mx/cierreagricola/

Soteriou GA, Kyriacou MC (2015). Rootstock-mediated effects on watermelon field performance and fruit quality characteristics. International Journal of Vegetable Science 21(4):344-362. https://doi.org/10.1080/19315260.2014.881454

Steiner AA (1961). A universal method for preparing nutrient solutions of a certain desired composition. Plant and Soil 15(2):134-154. https://doi.org/10.1007/BF01347224

Velasco-Alvarado MDJ, Lobato-Ortiz R, García-Zavala JJ, Castro-Brindis R, Cruz-Izquierdo S, Corona-Torres T (2019). Injertos interespecíficos entre Solanum lycopersicum L. y S. habrochaites Knapp \& Spooner como alternativa para incrementar el rendimiento de fruto [Interspecific grafts between Solanum lycopersicum L. and S. habrochaites Knapp \& Spooner as an alternative to increase fruit yield]. Agrociencia 53(7):1029-1042.

Vera-Guzmán AM, Aquino-Bolaños EN, Heredia-García E, Carrillo-Rodríguez JC, Hernández-Delgado S, ChávezServia JL (2017). Flavonoid and capsaicinoid contents and consumption of Mexican chili pepper (Capsicum annuum L.) landraces. Flavonoids-from biosynthesis to human health. InTechOpen 405-437. https://doi.org/10.5772/68076

Wilkinson (1979). The plant surface (mainly leaf). London: Oxford University pp 97-165.

Xu Q, Guo SR, Li L, An YH, Shu S, Sun J (2016). Proteomics analysis of compatibility and incompatibility in grafted cucumber seedlings. Plant Physiology and Biochemistry 105:21-28. https://doi.org/10.1016/j.plaphy.2016.04.001

Zhu J, Li J, Shen Y, Liu S, Zeng N, Zhan X, Xing B (2020). Mechanism of zinc oxide nanoparticle entry into wheat seedling leaves. Environmental Science: Nano 7(12):3901-3913. https://doi.org/10.1039/DOEN00658K
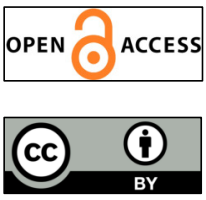

The journal offers free, immediate, and unrestricted access to peer-reviewed research and scholarly work. Users are allowed to read, download, copy, distribute, print, search, or link to the full texts of the articles, or use them for any other lawful purpose, without asking prior permission from the publisher or the author.

License - Articles published in Notulae Botanicae Horti Agrobotanici Cluj-Napoca are Open-Access, distributed under the terms and conditions of the Creative Commons Attribution (CC BY 4.0) License.

(c) Articles by the authors; UASVM, Cluj-Napoca, Romania. The journal allows the author(s) to hold the copyright/to retain publishing rights without restriction. 